University of Nebraska - Lincoln

DigitalCommons@University of Nebraska - Lincoln

Agronomy \& Horticulture -- Faculty Publications

Agronomy and Horticulture Department

2004

\title{
Glyphosate Efficacy on Velvetleaf Varies with Application Time of Day
}

Aaron L. Waltz

University of Nebraska-Lincoln

Alex R. Martin

University of Nebraska-Lincoln

Fred W. Roeth

University of Nebraska-Lincoln, fwroeth41@gmail.com

John L. Lindquist

University of Nebraska-Lincoln, jlindquist1@unl.edu

Follow this and additional works at: https://digitalcommons.unl.edu/agronomyfacpub

Part of the Plant Sciences Commons

Waltz, Aaron L.; Martin, Alex R.; Roeth, Fred W.; and Lindquist, John L., "Glyphosate Efficacy on Velvetleaf Varies with Application Time of Day" (2004). Agronomy \& Horticulture -- Faculty Publications. 419. https://digitalcommons.unl.edu/agronomyfacpub/419

This Article is brought to you for free and open access by the Agronomy and Horticulture Department at DigitalCommons@University of Nebraska - Lincoln. It has been accepted for inclusion in Agronomy \& Horticulture -Faculty Publications by an authorized administrator of DigitalCommons@University of Nebraska - Lincoln. 


\title{
Glyphosate Efficacy on Velvetleaf Varies with Application Time of Day ${ }^{1}$
}

\author{
AARON L. WALTZ, ALEX R. MARTIN, FRED W. ROETH, and JOHN L. LINDQUIST ${ }^{2}$
}

\begin{abstract}
Field and growth chamber experiments determined the efficacy of temporal glyphosate applications on velvetleaf. Glyphosate was applied postemergence to velvetleaf periodically before and during light and after dark. In 1999, glyphosate at $840 \mathrm{~g}$ ae/ha applied before sunrise and after midday provided 54 and $100 \%$ velvetleaf control, respectively. In 2000, glyphosate at $840 \mathrm{~g} / \mathrm{ha}$ applied before sunrise, midday, and after sunset provided 69, 100, and 37\% velvetleaf control, respectively. In the growth chamber, glyphosate at $840 \mathrm{~g} / \mathrm{ha}$ applied before or after light reduced velvetleaf biomass 15 to $20 \%$ or 32 to $47 \%$, respectively, and reduced velvetleaf height $24 \%$ or 45 to $54 \%$, respectively. Velvetleaf control was consistently greater with glyphosate applications during light compared with dark, regardless of constant air temperature and relative humidity (growth chamber), dew absence or presence (field and growth chamber), or leaf blade orientation (growth chamber) with natural light-dark movements or a fixed horizontal position.
\end{abstract}

Nomenclature: Glyphosate; velvetleaf, Abutilon theophrasti Medic. \#3 ABUTH.

Additional index words: Application timing, differential response.

Abbreviations: DAT, days after treatment; POST, postemergence; PPFD, photosynthetic photon flux density; RH, relative humidity.

\section{INTRODUCTION}

Postemergence (POST) herbicide efficacy may be affected by environmental factors including light duration and intensity, air temperature, relative humidity $(\mathrm{RH})$, and dew or precipitation (Gerber et al. 1983; Hammerton 1967; Muzik 1976; Price 1983). These environmental conditions may influence processes such as herbicide absorption, translocation, or plant metabolism, which influence herbicide efficacy.

In 2001, glyphosate was applied to greater than $70 \%$ of the herbicide-treated soybean [Glycine $\max (\mathrm{L}$.) Merr.] hectarage in the United States (National Agricultural Statistics Service 2002). Glyphosate is used in glyphosate-resistant corn (Zea mays L.) and as a burndown in conventional no-tillage crops. With a strong reliance on glyphosate for weed control, understanding environmental influences on glyphosate activity will aid in optimum efficacy from each application.

As temperature increased, glyphosate efficacy on wild oat (Avena fatua L.) and liverseedgrass (Urochloa pan-

\footnotetext{
${ }^{1}$ Received for publication May 2, 2003, and in revised form April 5, 2004. Publication 13842 University of Nebraska Agricultural Research Division (ARD) Journal Series.

${ }^{2}$ Graduate Research Assistant, Professor, Professor, and Assistant Professor, respectively, Department of Agronomy and Horticulture, University of $\mathrm{Ne}$ braska-Lincoln, 279 Plant Science, Lincoln, NE 68583-0915. Corresponding author's E-mail: awaltz1@bigred.unl.edu.

${ }^{3}$ Letters following this symbol are a WSSA-approved computer code from Composite List of Weeds, Revised 1989. Available only on computer disk from WSSA, 810 East 10th Street, Lawrence, KS 66044-8897.
}

icoides Beauv.) increased (Adkins et al. 1998). However, changing light level from full to $50 \%$ sunlight did not change the response to glyphosate. Similarly, glyphosate activity on junglerice [Echinochloa colona (L.) Link] increased as temperature increased from 20 to $35 \mathrm{C}$, but glyphosate activity was unaffected by different lightdark periods (Tanpipat et al. 1997).

Temperature also influenced ${ }^{14} \mathrm{C}$-glyphosate absorption by cultured velvetleaf cells (Røyneberg et al. 1992). Nearly twice as much glyphosate was absorbed at $28 \mathrm{C}$ than at 16 or 4 C. Similar temperature effects were observed with bermudagrass [Cynodon dactylon (L.) Pers.] (Jordan 1977) and johnsongrass (Sorghum halepense L.) (McWhorter et al. 1980).

Glyphosate activity or absorption increased with increasing RH for quackgrass [Elytrigia repens (L.) Nevski] (McIntyre and Hsiao 1982), bermudagrass (Jordan 1977), liverseedgrass (Adkins et al. 1998), junglerice (Tanpipat et al. 1997), and johnsongrass (McWhorter et al. 1980). Generally, high RH and high temperatures, as well as low light intensity before treatment followed by high light intensity after treatment, increase plant susceptibility to POST herbicides (Hammerton 1967). Dew and precipitation may also influence glyphosate activity because glyphosate activity decreased when dew was present at or formed after application (Behrens 1977).

The increase in glyphosate-resistant crops and a greater reliance on POST glyphosate use reinforces the im- 
portance of applying glyphosate according to the proper crop and weed growth stage. Consequently, more glyphosate applications are made during predawn, evening, and nighttime hours due to time constraints and the minimal influence of spray drift. Inconsistent glyphosate control has suggested that the time of application may influence efficacy.

Under growth chamber conditions, no difference in glyphosate activity on quackgrass was evident between 12-h light, 6-h light/6-h dark, or 6-h dark/6-h light periods after application (Caseley and Coupland 1983). However, differences between these treatments and treatments made at the beginning of the dark period (12-h dark after application) were reported. They concluded that glyphosate absorption, movement, and efficacy were influenced by the light period before and after application. Hemp sesbania [Sesbania exaltata (Raf.) Rydb.], sicklepod (Senna obtusifolia), and prickly sida (Sida spinosa L.) control was greatest with glyphosate applied during the daylight hours, with greater herbicide interception attributed to a more horizontal leaf orientation (Norsworthy et al. 1999).

Palmer amaranth [Amaranthus palmeri (S.) Wats.] and velvetleaf control was greater with glyphosate applied at 10:00 A.M., 1:30 P.M., and 5:30 P.M. than when applied at 6:00 A.M. and 9:00 P.M. (Peterson and Al-Khatib 1999). Differential glyphosate response was attributed to the presence of dew, diurnal leaf movement, or physiological light interactions within plants. Annual grass and broadleaf weed control was greatest with glyphosate applications between 9:00 A.M. and 6:00 P.M. (Martinson 2000), with differences attributed to diurnal plant rhythms and environmental conditions at application, including temperature, $\mathrm{RH}$, and dew.

The objectives of this research were to examine application time of day on glyphosate efficacy and determine factors affecting variable glyphosate activity.

\section{MATERIALS AND METHODS}

Field Experiments. Field experiments were conducted in 1999 and 2000 at the University of Nebraska Agronomy Research Farm in Lincoln, NE. The soil was a Sharpsburg silty clay loam (fine, montmorillonitic, mesic Typic Arguidolls), with a $\mathrm{pH}$ of 6.5 and $3.1 \%$ organic matter. The experimental design was a split-plot randomized complete block with four replications. Application timing was the main plot, and glyphosate rate was the subplot. The experiment was conducted on four dates in 1999 and six dates in 2000. Seedbeds were prepared by disking and field cultivation.
Plots consisted of four 0.76-m-spaced rows, $6.1 \mathrm{~m}$ in length. Velvetleaf seeds were sown in monoculture using the insecticide boxes on a John Deere 7100 six-row planter. ${ }^{4}$ Velvetleaf was chosen as a model species because it is an important economic problem (Bridges 1992; Spencer 1984) and has a wide germination period allowing repeated experiments within a growing season. The seed was planted at approximately 90 seeds per meter of row with a target depth of 1 to $2 \mathrm{~cm}$.

Metolachlor at $1.6 \mathrm{~kg}$ ai/ha was applied preemergence (no difference was observed in emerged velvetleaf) or sethoxydim at $0.2 \mathrm{~kg}$ ai/ha was applied POST (2 wk before glyphosate application) for grass control. Mechanical interrow and hand cultivations controlled other weeds. One week before glyphosate application, velvetleaf plants were thinned to 20 plants per 3-m row.

Because of the changing photoperiod throughout the summer, applications were on the basis of normalized photoperiod, with sunrise equal to 0.0 and sunset equal to 1.0. This approach provided uniform identification of treatments between experiments that received the same relative amount of sunlight before and after treatment. The five application times for the first two experiments in 1999 were $0.1,0.3,0.5,0.7$, and 0.9. The third and fourth experiments in 1999 also included two additional application times of -0.1 (before sunrise) and 1.1 (after sunset). All experiments in 2000 had nine application timings: $-0.1,0.0,0.1,0.2,0.3,0.6,0.9,1.1$, and 1.3. Application dates and times are shown in Table 1. In each experiment, five glyphosate ${ }^{5}$ rates were applied POST. The glyphosate rates for 1999 included 0, 210, 420,630 , and $840 \mathrm{~g}$ ae/ha. In 2000, the glyphosate rates included $0,315,420,630$, and $840 \mathrm{~g} / \mathrm{ha}$. No additives were included in the spray solution. The herbicide was applied in $94 \mathrm{~L} / \mathrm{ha}$ at $170 \mathrm{kPa}$ with flat-fan nozzles on a tractor-mounted, compressed air-pressurized sprayer.

One fully expanded leaf blade on one velvetleaf plant within each plot was sampled before application time with an LI-6200 Portable Photosynthesis System ${ }^{6}$. This system uses a $\mathrm{CO}_{2}$ analyzer and leaf temperature, air temperature, $\mathrm{RH}$, and photosynthetic photon flux density (PPFD) measurements to calculate photosynthetic rate, transpiration rate, and stomatal conductance. Environmental data were recorded at a High Plains Regional Climate Center automated weather station, ${ }^{7} 1 \mathrm{~km}$ from the field site in 1999 and with a Kestrel 3000 handheld

\footnotetext{
${ }^{4}$ Deere \& Company, One John Deere Place, Moline, IL 61265-8098.

${ }^{5}$ Roundup Ultra, Monsanto Company, $800 \mathrm{~N}$ Lindbergh Boulevard., St. Louis, MO 63167.

${ }^{6}$ LI-COR Inc., P.O. Box 4425, Lincoln, NE 68504.

${ }^{7}$ www.hprcc.unl.edu/index.html (data obtained September 24, 1999).
} 
weather station ${ }^{8}$ in 2000 (Table 1). Velvetleaf surface dew presence was classified No (not visibly wet and dry to touch), Slight (not visibly wet but damp to touch), or Yes (visibly wet). Velvetleaf height $(23 \mathrm{~cm}[ \pm 6]$ average) and leaf stage (9 [ \pm 2$]$ average) were recorded for at least two plants within each plot.

A leaf blade angle measurement was made on one randomly selected, fully expanded leaf blade on one plant in each plot before glyphosate application in 2000. Similar to Andersen and Koukkari (1978), the angle between a horizontal plane perpendicular to the stem and the leaf blade was measured with a protractor $\left(0^{\circ}\right.$ indicated a leaf blade perpendicular to the stem, and $-90^{\circ}$ indicated a leaf blade parallel to the stem pointing downward).

Velvetleaf mortality, injury, and freshweight biomass were determined $14 \mathrm{~d}$ after treatment (DAT). Plots were scored according to the 20 velvetleaf plants within each plot. A mortality rating was based on 0 to 20: 0 indicated no plants dead, whereas 20 indicated all plants dead. A plant was designated alive if, at the time of measurement, new buds or growth had formed. Mortality ratings were converted to percent control by multiplying by five.

Injury ratings ranged from 0 (healthy, green plants) to 100 (brown, completely necrotic plants). The freshweight biomass measurement (top growth production only) consisted of clipping plants at the soil surface and collectively weighing all 20 plants within each plot. Injury ratings and freshweight biomass measurements correlated to percent control; only percent control is discussed.

Growth Chamber Experiments. Four velvetleaf seeds were planted in 11.5 -cm-diam $\times 10$-cm-deep pots containing a 19:9:1 (by wt) mixture of soil (sterilized Sharpsburg silty clay loam), sand, and vermiculite; plants were thinned to one per pot. Plants were watered daily and supplemented once per week with a fertilizer solution. Plants were grown in a greenhouse at $25 \mathrm{C}$ $( \pm 10 \mathrm{C})$ and $50 \%( \pm 10 \%) \mathrm{RH}$. Sodium halide lights provided approximately $500 \mu \mathrm{mol} / \mathrm{m}^{2} / \mathrm{s}$ supplemental PPFD with a 15:9 h light-dark photoperiod. Velvetleaf plants were placed in the growth chamber $3 \mathrm{~d}$ before application. The growth chamber was maintained at 23 $\mathrm{C}( \pm 3 \mathrm{C})$ with 60 to $70 \% \mathrm{RH}$.

The experimental design was a completely randomized block with four replications of one plant per treatment. The experiment was conducted twice. The treatment design was a factorial arrangement consisting of

\footnotetext{
${ }^{8}$ Nielson-Kellerman, 104 West 15th Street, Chester, PA 19013.
}

three factors: application time, glyphosate rate, and leaf blade orientation. Six application times were used: -0.1 , $0.1,0.5,0.9,1.1$, and 1.3, which correspond to clock times of 4:30, 7:30, 13:30, 19:30, 22:30, and 1:30. The normalized light period began at 0.0 when the lights in the growth chamber turned on, with the lights turning off at 1.0.

Herbicide treatments were a nontreated control and $840 \mathrm{~g} /$ ha glyphosate ${ }^{5}$. At application, average velvetleaf height was $16 \mathrm{~cm}$ and leaf stage was eight. Glyphosate was applied with distilled water as the carrier in a volume equivalent to $94 \mathrm{~L} / \mathrm{ha}$ at $220 \mathrm{kPa}$ with a compressed $\mathrm{CO}_{2}$-pressurized backpack sprayer.

The two leaf blade orientations used for the experiment were natural and horizontal. Three fully expanded leaf blades on half the plants were supported adaxially with circular loops of copper wire $1 \mathrm{~d}$ before application to maintain a horizontal leaf blade orientation. Half the plants had a natural leaf blade orientation: leaf blades moved naturally, without support.

A LI-6200 Portable Photosynthesis System ${ }^{6}$ was used as before to measure each velvetleaf plant before treatment. Leaf blade angles were measured on each plant with a natural leaf blade orientation. Dark measurements were made with the aid of flashlights covered with green tissue paper (adapted from Andersen and Koukkari 1978). Response variables measured 21 DAT included injury, as discussed previously, as well as height and freshweight biomass. Individual plants were scored as a single unit. Biomass measurements (top growth production only) consisted of clipping each plant at the soil surface and weighing the plant. Injury ratings correlated to height and freshweight biomass measurements. Only height and freshweight biomass reduction are discussed.

Proc Mixed in $\mathrm{SAS}^{9}$ was used to test interactions and main effects with ANOVA, and to test treatment differences using pairwise $t$-tests at $\alpha=0.05$. Field experiment analyses included height and leaf stage as possible covariates with glyphosate efficacy. Line-scatter plots were constructed to determine the relationships between individual field parameters and glyphosate efficacy. Proc Corr in $\mathrm{SAS}^{9}$ was used to estimate Pearson product moment correlations $(r)$.

\section{RESULTS AND DISCUSSION}

Field Experiments. Because of precipitation differences between 1999 (7 cm above 30-yr average) and 2000 (21 cm below 30-yr average), slightly different application

\footnotetext{
${ }^{9}$ SAS Institute Inc. 1996. Box 8000, SAS Circle, Cary, NC 25711-8000.
} 


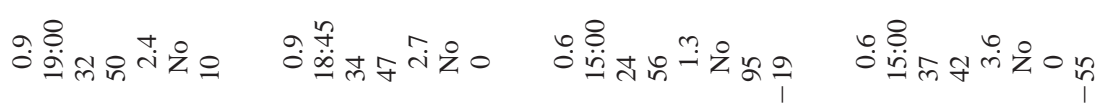

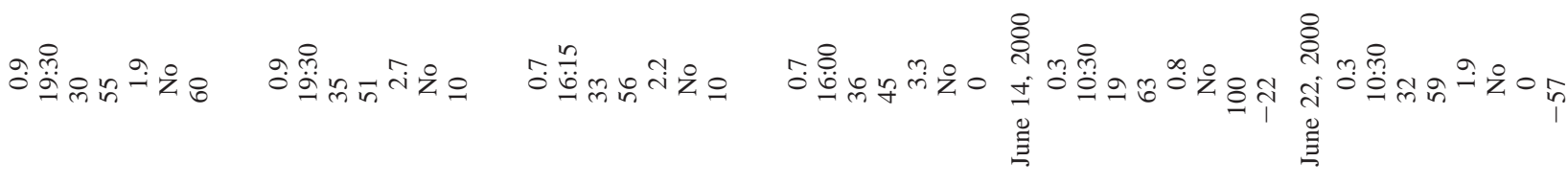

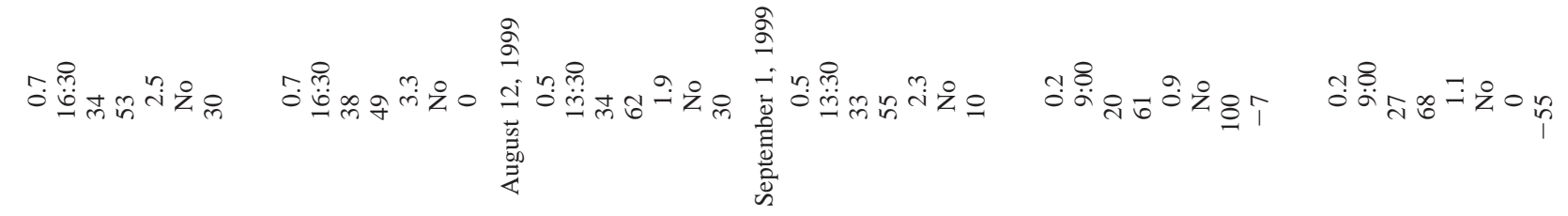

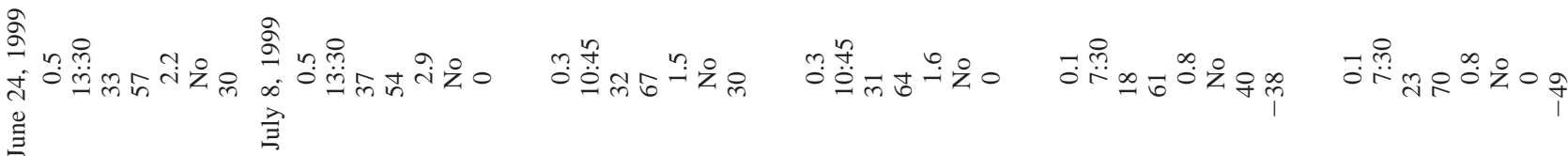

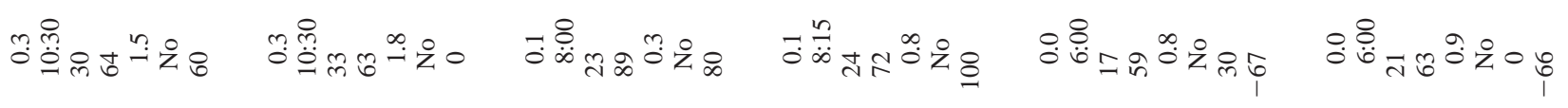

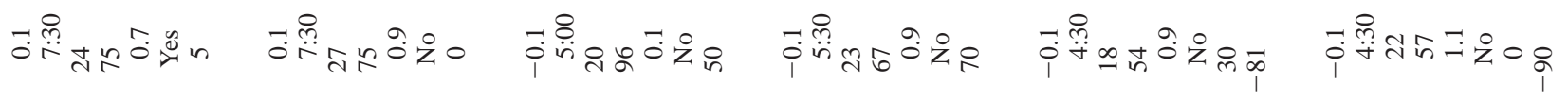

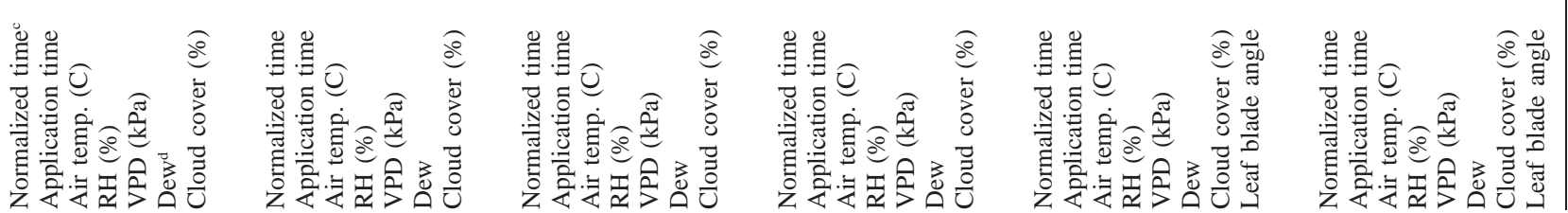


WEED TECHNOLOGY

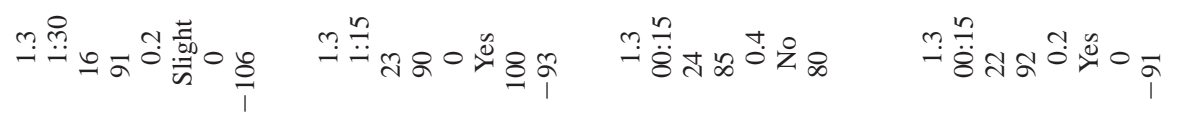

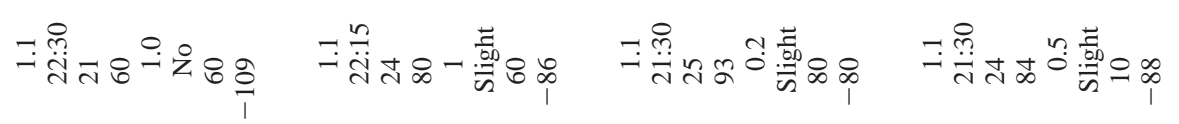

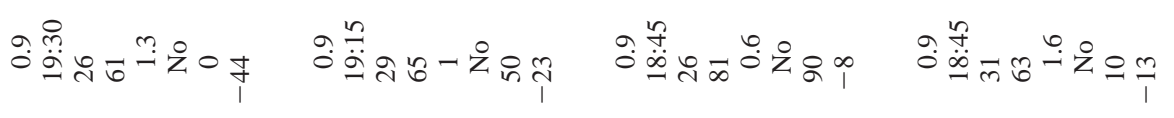

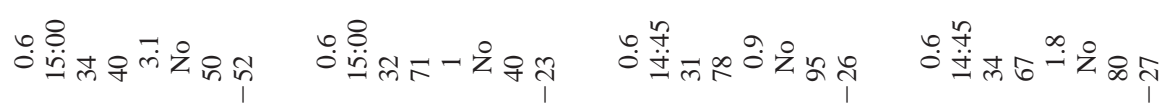

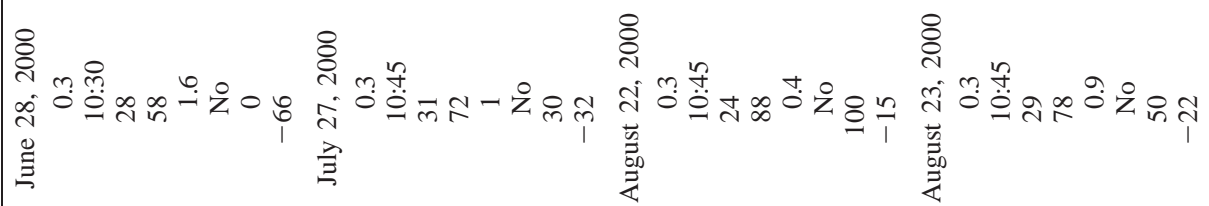

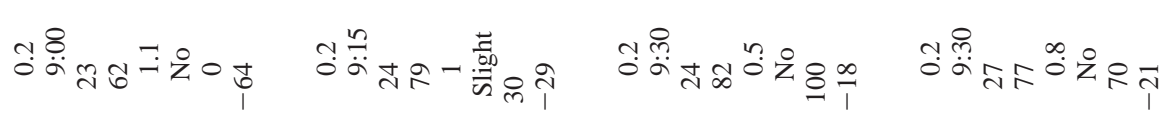

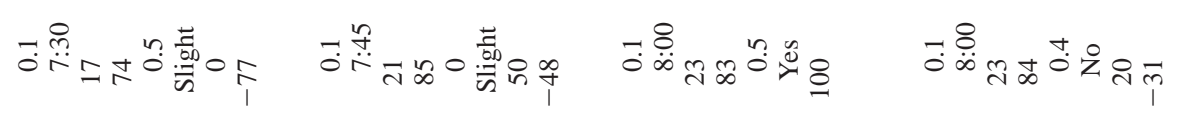

$$
\begin{aligned}
& \text { : 这m }
\end{aligned}
$$

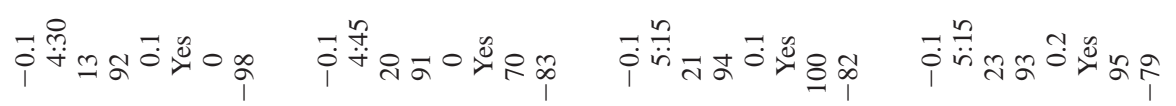

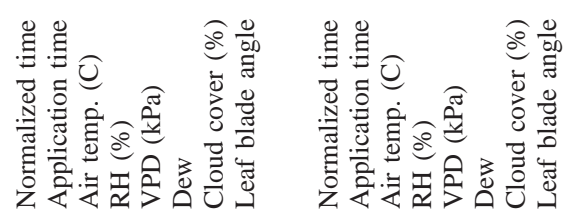

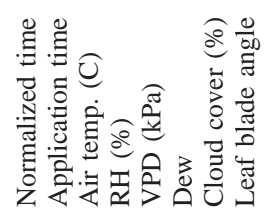

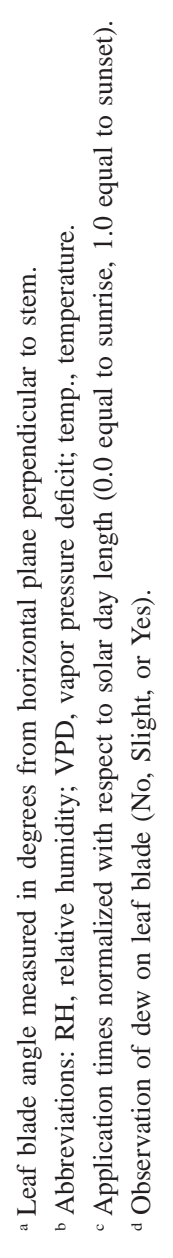



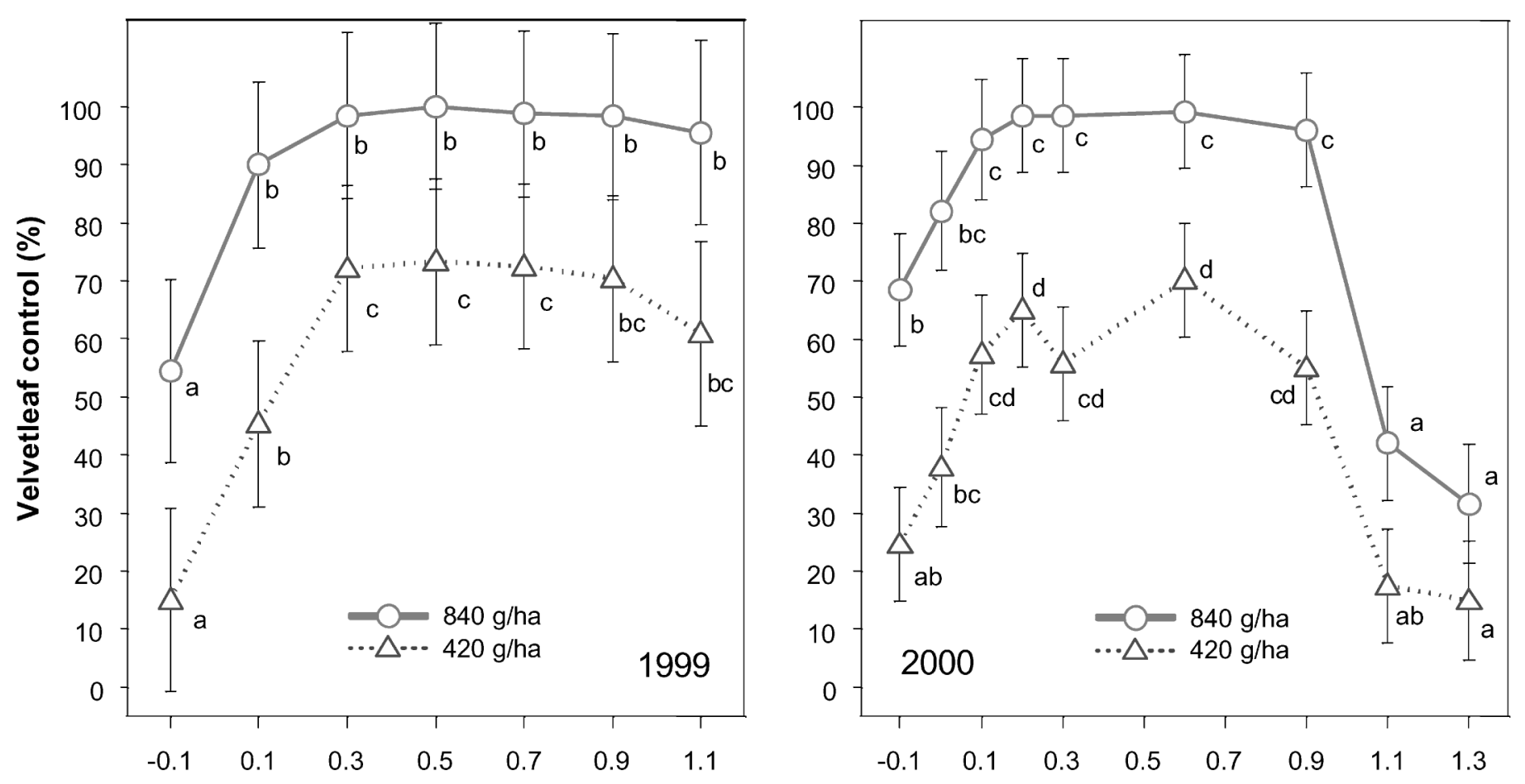

Normalized daylength application time

Figure 1. Velvetleaf control in the field with glyphosate applied at various times of day in 1999 and 2000. Application times are based on a normalized photoperiod $(0.0=$ sunrise and $1.0=$ sunset). Data points are means of three (1999) or six (2000) experiments. Error bars are 1 SE of the mean. Data points are compared across application times within a rate, not across rates. Data points followed by the same letter do not differ significantly at $\alpha=0.05$.

times, and an experiment by year interaction, data were not combined across years. With no significant main effect for experiment, results were combined within years. Covariate analyses indicated that velvetleaf height $(23$ $\mathrm{cm}[ \pm 6]$ average) and leaf stage $(9[ \pm 2]$ average $)$ were not significant (data not shown).

In 1999, velvetleaf control was lower with glyphosate applied before sunrise than later in the day (Figure 1). Glyphosate at $420 \mathrm{~g} / \mathrm{ha}$ controlled velvetleaf $15 \%$ before sunrise and $73 \%$ at midday. At $840 \mathrm{~g} / \mathrm{ha}$ glyphosate, velvetleaf control was $54 \%$ before sunrise and nearly $100 \%$ at midday and later. Glyphosate applied before sunrise and after sunset was least effective in 2000. Glyphosate at $420 \mathrm{~g} / \mathrm{ha}$ controlled velvetleaf $25 \%$ before sunrise, $70 \%$ at midday, and 15 to $18 \%$ after sunset. With 840 $\mathrm{g} /$ ha glyphosate, velvetleaf control was $69 \%$ before sunrise, nearly $100 \%$ at midday, and 32 to $42 \%$ after sunset. The lowest glyphosate rates (210 g/ha in 1999 and 315 $\mathrm{g} / \mathrm{ha}$ in 2000) resulted in little velvetleaf response regardless of application time (data not shown). The variation in velvetleaf control with application time with $630 \mathrm{~g} / \mathrm{ha}$ glyphosate was similar to that with 420 and $840 \mathrm{~g} / \mathrm{ha}$ glyphosate.

On August 22 and 23, 2000, glyphosate was least ef- fective when applied before sunrise and after sunset. However, glyphosate at $420 \mathrm{~g} / \mathrm{ha}$ controlled velvetleaf $0 \%$ before sunrise and 95\% at midday on August 22. Velvetleaf control with $420 \mathrm{~g} /$ ha glyphosate was $14 \%$ before sunrise and 38 to 53\% at midday on August 23 (data not shown). Climatological data are shown in Table 1.

Growth Chamber Experiments. Because experiment by time interaction was not significant, the experiments were combined for analysis. With $840 \mathrm{~g} / \mathrm{ha}$ glyphosate, natural leaf blade velvetleaf biomass was reduced $15 \%$ before light and 33 to $43 \%$ after light, and velvetleaf height was reduced $24 \%$ before light and 45 to $54 \%$ after light (Figure 2). With $840 \mathrm{~g} /$ ha glyphosate applications to horizontal leaf blade velvetleaf, biomass was reduced $20 \%$ before light and 32 to $47 \%$ after light, and velvetleaf height was reduced $24 \%$ before light and 46 to $52 \%$ after light.

Velvetleaf biomass reduction with glyphosate applied before light was significantly less than applications at midday $(0.5)$ for both natural and horizontal leaf blade plants. Velvetleaf height for natural and horizontal leaf blade plants was reduced the least with glyphosate applied before light. 

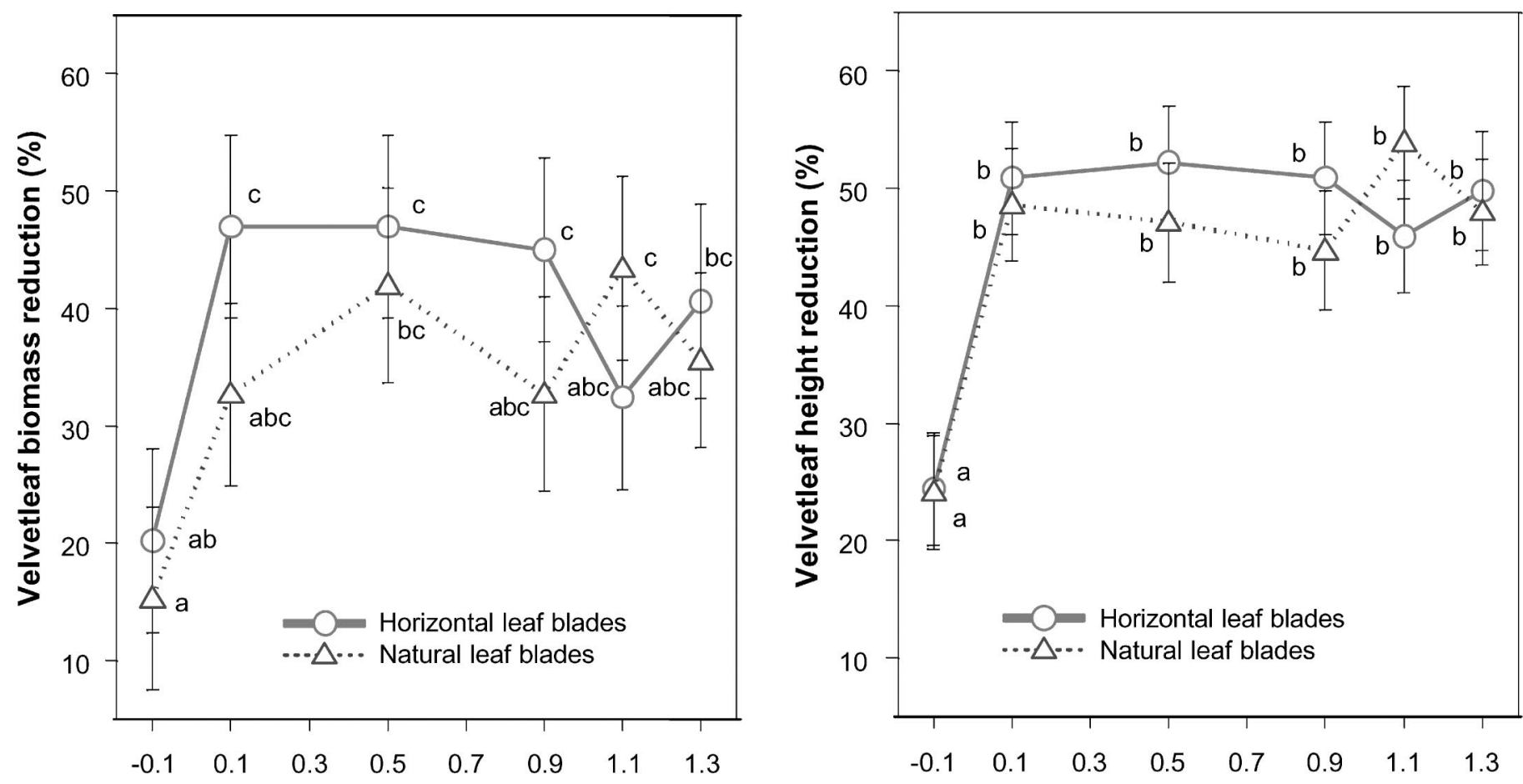

Normalized $15 \mathrm{~h}$ light period application time

Figure 2. Velvetleaf biomass and height reduction in the growth chamber with glyphosate ( $840 \mathrm{~g} / \mathrm{ha})$ applied at various times of day. Application times are normalized with respect to light period $(0.0=$ lights turned on and $1.0=$ lights turned off). Data points are means of two experiments. Error bars are $1 \mathrm{SE}$ of the mean. Data points are compared across application time and leaf blade orientation. Data points followed by the same letter do not differ significantly at $\alpha$ $=0.05$.

Factors Contributing to Velvetleaf Response. In the field, air temperature at application time was directly related $(r=0.29)$ with velvetleaf response to glyphosate (Figure 3A). Elevated air temperature may increase penetration by "softening" the wax cuticle structure, allowing more herbicide movement into and through the cuticular waxes (Willingham and Graham 1988). Higher temperatures increase plant metabolism rates, translocation, and herbicide absorption (Price 1983). However, the light regime in the growth chamber affected glyphosate efficacy with constant temperature $( \pm 3 \mathrm{C})$. Air temperature may influence efficacy, but it is probably not the main factor controlling velvetleaf response to glyphosate application time.

RH was inversely correlated to glyphosate activity ( $r$ $=-0.51$ ) in the field (Figure 3A). The greatest glyphosate activity occurred during times of lowest RH (and greatest vapor pressure deficit). Velvetleaf response also varied with glyphosate application time in a constant humidity growth chamber (60 to $70 \%$ RH). High RH may prolong droplet solution duration, hydrate plant cuticles and facilitate herbicide absorption (Muzik 1976), and increase partitioning of polar herbicides, such as glyphos- ate, into the lipid-rich cuticle (Kudsk et al. 1990). However, glyphosate efficacy differences with changing field and constant growth chamber conditions indicate $\mathrm{RH}$ may contribute but is probably not the main factor controlling velvetleaf response to glyphosate application time.

Velvetleaf leaf blade angles change dramatically throughout the day in the field (Table 1). Leaf blades can orient from nearly horizontal to nearly vertical. Horizontal leaf blades can potentially intercept more herbicide solution than vertical leaf blades. However, glyphosate activity in the growth chamber varied with application time regardless of natural or horizontal leaf blade orientation (Figure 2). Velvetleaf leaf blade angle may contribute but is not the main factor controlling velvetleaf response with glyphosate application time.

Dew could increase glyphosate efficacy by allowing herbicide and adjuvant to remain in solution longer, facilitating absorption. Dew could increase herbicide loss by leaf surface runoff or decrease absorption with lower herbicide and adjuvant droplet concentrations. Velvetleaf response varied with glyphosate application time, June 14 and July 27, 2000 (individual data not shown, data 


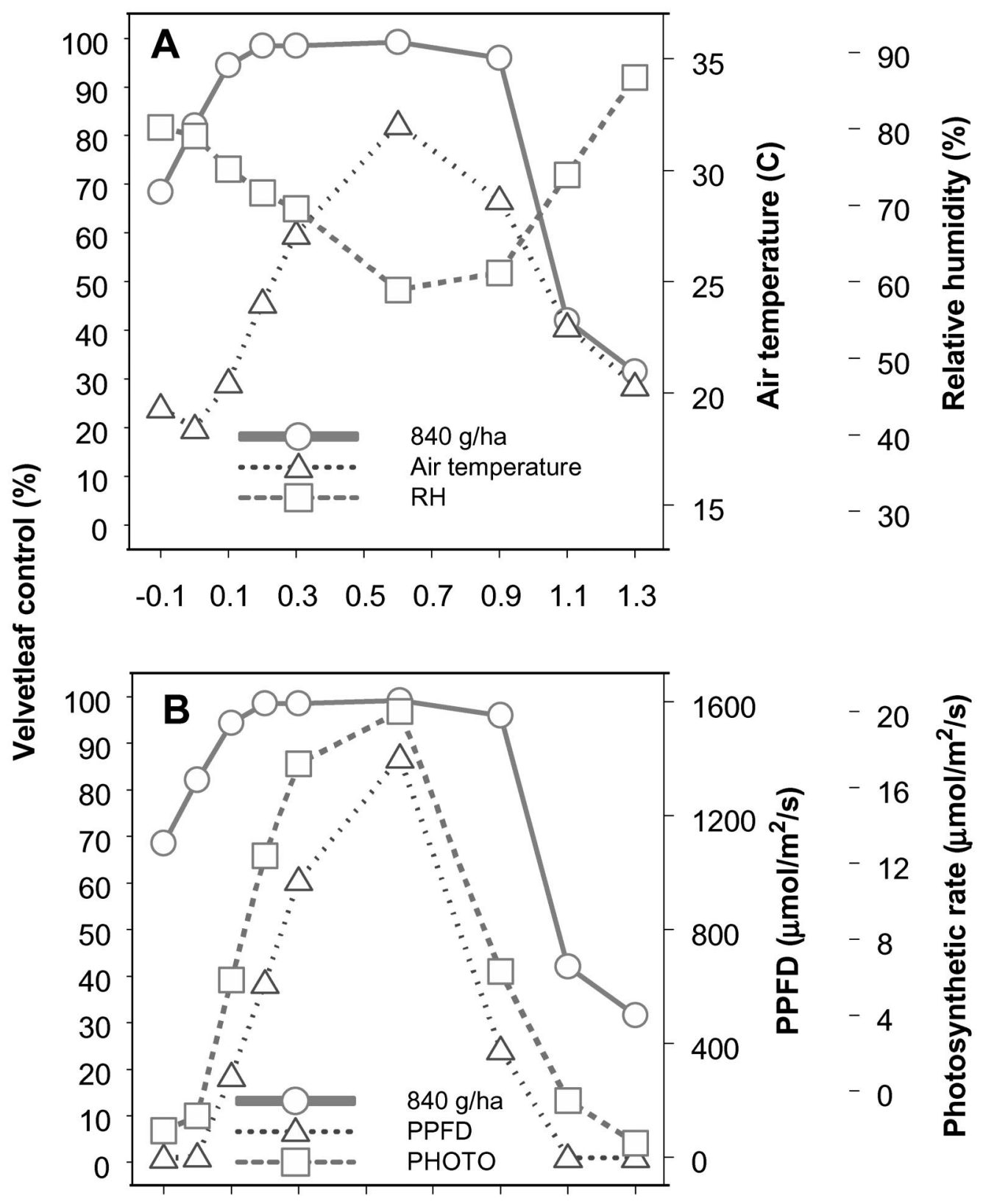

\section{$\begin{array}{llllllll}-0.1 & 0.1 & 0.3 & 0.5 & 0.7 & 0.9 & 1.1 & 1.3\end{array}$}

Normalized application time

Figure 3. Velvetleaf control in the field with glyphosate applied at various times of day compared with (A) air temperature $(r=0.29)$ and relative humidity $(r$ $=-0.51)$, (B) photosynthetic photon flux density (PPFD) $(r=0.40)$ and photosynthetic rate (PHOTO) $(r=0.47)$. Data points are means of six experiments in 2000 .

points incorporated in Figure 1). Dew was not present at any time on June 14, 2000, but on July 27, 2000, dew was present at numerous application times (Table 1). Velvetleaf response varied with glyphosate application time in the growth chamber, where dew was not present. Increases in glyphosate efficacy regardless of dew absence or presence indicate dew was not influential in these studies, and it may contribute, but is not the main factor controlling velvetleaf response to glyphosate application time.

In the field, velvetleaf response to glyphosate appears directly correlated to PPFD ( $r=0.40)$ (Figure 3B). Glyphosate treatments to quackgrass made at the beginning of the dark period (12-h dark after application) were less 
effective than treatments with 12-h light, 6-h light/6-h dark, or 6-h dark/6-h light periods after application (Caseley and Copeland 1983). They concluded glyphosate absorption, movement, and efficacy were influenced by the light period before and after application. The influence of the light environment on glyphosate absorption could partially explain the decrease in velvetleaf response in these experiments.

PPFD and photosynthetic rate are directly related. PPFD will relate to the physiological status of the plant at application time. Velvetleaf response to glyphosate appears directly correlated to photosynthetic rate $(r=0.47)$ in the field (Figure 3B). Because glyphosate is a translocated herbicide, greater photosynthetic rate, which would increase metabolite transport throughout the plant, could possibly increase glyphosate transport.

In field and growth chamber experiments, glyphosate applications to velvetleaf during relatively high photosynthesis were most effective. In both the field and growth chamber, velvetleaf plants are photosynthetically less active before sunrise (or light period) than throughout the rest of the day. Environmental and plant conditions near application time are important for herbicide uptake. Feng et al. (2000) reported most of the total glyphosate uptake into velvetleaf occurred by $24 \mathrm{~h}$ after treatment, suggesting efficient uptake is a major determinant in glyphosate efficacy. However, the change in photosynthetic activity does not fully explain the lack of a decrease in velvetleaf response with applications after dark in the field (1999) and growth chamber. This finding might reflect the movement of glyphosate with excess photosynthetic sugars from source to sink during the early part of the dark period.

Controlled air temperature, $\mathrm{RH}$, and leaf blade orientations, along with experimental observations on dew, essentially eliminate these variables as single main factors controlling velvetleaf response to glyphosate application time. We believe that some function of the changing light environment and the effect on glyphosate uptake or internal plant processes (photosynthetic rate or related physiological indicator) may better explain this variation.

\section{ACKNOWLEDGMENTS}

Our special thanks to Jess Spotanski for help with the early morning and late night applications. We also thank
Dr. Linda Young for statistical input and many reviewers for their editorial content.

\section{LITERATURE CITED}

Adkins, S. W., S. Tanpipat, J. T. Swarbrick, and M. Boersma. 1998. Influence of environmental factors on glyphosate when applied to Avena fatua or Urochloa panicoides. Weed Res. 38:129-138.

Andersen, R. N. and W. L. Koukkari. 1978. Response of velvetleaf (Abutilon theophrasti) to bentazon as affected by leaf orientation. Weed Sci. 26: 393-395.

Behrens, R. 1977. Influence of dew on the phytotoxicity of foliarly applied herbicides. Proc. North Central Weed Control Conf. 32:116.

Bridges, D. C., ed. 1992. Crop Losses Due to Weeds in Canada and the United States. WSSA Weed Loss Committee. Lawrence, KS: Weed Science Society of America. P. 115.

Caseley, J. C. and D. Coupland. 1983. Day compared with night application of glyphosate for Elymus repens control in cereals. Asp. Appl. Biol. 4: 301-307.

Feng, P.C.C., J. Joseph Sandbrink, and R. Douglas Sammons. 2000. Retention, uptake, and translocation of ${ }^{14} \mathrm{C}$-glyphosate from track-spray applications and correlation to rainfastness in velvetleaf (Abutilon theophrasti). Weed Technol. 14:127-132.

Gerber, H. R., A. Nyffeler, and D. H. Green. 1983. The influence of rainfall, temperature, humidity and light on soil- and foliar-applied herbicides. Asp. Appl. Biol. 4:1-14.

Hammerton, J. L. 1967. Environmental factors and susceptibility to herbicides. Weeds 15:330-335.

Jordan, T. N. 1977. Effects of temperature and relative humidity on the toxicity of glyphosate to bermudagrass (Cynodon dactylon). Weed Sci. 25: 448-451.

Kudsk, P., T. Olesen, and K. E. Thonke. 1990. The influence of temperature, humidity and simulated rainfall on the performance of thiameturon-methyl. Weed Res. 30:261-269.

Martinson, K. B. 2000. The Effect of Time of Day of Application, Rate and Adjuvant on Annual Weed Control with Glyphosate and Glufosinate. M.S. thesis. University of Minnesota, St. Paul, MN. Pp. 53-57.

McIntrye, G. I. and A. I. Hsiao. 1982. Influence of nitrogen and humidity on rhizome bud growth and glyphosate translocation in quackgrass (Agropyron repens). Weed Sci. 30:655-660.

McWhorter, C. G., T. N. Jordan, and G. D. Wills. 1980. Translocation of ${ }^{14} \mathrm{C}-$ glyphosate in soybeans (Glycine max) and johnsongrass (Sorghum halepense). Weed Sci. 28:113-118.

Muzik, T. J. 1976. Influence of environmental factors on toxicity to plants. In L. J. Audus, ed. Herbicides: Physiology, Biochemistry, Ecology, Volume 1. London: Academic. Pp. 203-247.

National Agricultural Statistics Service. 2002. Agricultural Chemical Usage, 2001 Field Crops Summary. Washington, DC: United States Department of Agriculture. Pp. 58, 64.

Norsworthy, J. K., L. R. Oliver, and L. C. Purcell. 1999. Diurnal leaf movement effects on spray interception and glyphosate efficacy. Weed Technol. 13:466-470.

Peterson, D. E. and K. Al-Khatib. 1999. The influence of application time of day on glyphosate efficacy. Proc. North Central Weed Sci. Soc. 54:17-18.

Price, C. E. 1983. The effect of environment on foliage uptake and translocation of herbicides. Asp. Appl. Biol. 4:157-169.

Røyneberg, T., N. E. Balke, and K. Lund-Høie. 1992. Effects of adjuvants and temperature on glyphosate absorption by cultured cells of velvetleaf (Abutilon theophrasti Medic.). Weed Res. 32:419-428.

Spencer, N. R. 1984. Velvetleaf, Abutilon theophrasti (Malvaceae), history and economic impact in the United States. Econ. Bot. 38:407-416.

Tanpipat, S., S. W. Adkins, J. T. Swarbrick, and M. Boersma. 1997. Influence of selected environmental factors on glyphosate efficacy when applied to awnless barnyard grass (Echinochloa colona (L.) Link). Aust. J. Agric. Res. 48:695-702.

Willingham, G. L. and L. L. Graham. 1988. Influence of environmental factors and adjuvants on the foliar penetration of acifluorfen in velvetleaf ( $A b u$ tilon theophrasti): an analysis using the fractional factorial design. Weed Sci. 36:824-829. 